\title{
Peroxisome proliferator-activated receptor $\beta / \delta$ : a master regulator of metabolic pathways in skeletal muscle
}

\author{
Shawon Lahiri and Walter Wahli* \\ Center for Integrative Genomics, National Research Center \\ "Frontiers in Genetics", University of Lausanne, \\ Lausanne, Switzerland
}

\begin{abstract}
Skeletal muscle is considered to be a major site of energy expenditure and thus is important in regulating events affecting metabolic disorders. Over the years, both in vitro and in vivo approaches have established the role of peroxisome proliferator-activated receptor- $\beta / \delta(\operatorname{PPAR} \beta / \delta)$ in fatty acid metabolism and energy expenditure in skeletal muscles. Pharmacological activation of PPAR $\beta / \delta$ by specific ligands regulates the expression of genes involved in lipid use, triglyceride hydrolysis, fatty acid oxidation, energy expenditure, and lipid efflux in muscles, in turn resulting in decreased body fat mass and enhanced insulin sensitivity. Both the lipid-lowering and the anti-diabetic effects exerted by the induction of PPAR $\beta / \delta$ result in the amelioration of symptoms of metabolic disorders. This review summarizes the action of PPAR $\beta / \delta$ activation in energy metabolism in skeletal muscles and also highlights the unexplored pathways in which it might have potential effects in the context of muscular disorders. Numerous preclinical studies have identified PPAR $\beta / \delta$ as a probable potential target for therapeutic interventions. Although PPAR $\beta / \delta$ agonists have not yet reached the market, several are presently being investigated in clinical trials.
\end{abstract}

Keywords: fatty acid oxidation; lipid metabolism; muscle fiber switching; obesity; peroxisome proliferator-activated receptor- $\beta / \delta(\operatorname{PPAR} \beta / \delta)$.

$\begin{array}{ll}\text { Abbreviations } & \\ \text { ABCA } & \text { ATP binding cassette } \\ \text { ACS } & \text { acyl-CoA synthetase } \\ \text { ADRP } & \text { adipocyte differentiation-related protein } \\ \text { AMPK } & \text { AMP-activated protein kinase } \\ \text { ApoE } & \text { apolipoprotein-E } \\ \text { COX } & \text { cytochrome c oxidase } \\ \text { CPT } & \text { carnitine-palmitoyl transferase }\end{array}$

* Corresponding author: Walter Wahli, Center for Integrative Genomics, Genopode Building, University of Lausanne, 1015 Lausanne, Switzerland

Phone: +41-21-692-4110, Fax: +41-21-692-4115,

E-mail:walter.wahli@unil.ch

Received November 22, 2010; accepted November 23, 2010; previously published online January 21,2011

$\begin{array}{ll}\text { CS } & \text { creatine synthase } \\ \text { FABP/hFABP } & \text { heart fatty-acid binding protein } \\ \text { fatty acid translocase } \\ \text { GLUT4 } & \text { glucose transporter } 4 \\ \text { LCAD, MCAD, } & \text { ong, medium and short-chain } \\ \text { and SCAD } & \text { acyl-CoA dehydrogenase } \\ \text { LCAS } & \text { long chain acyl-CoA synthetase } \\ \text { LPL } & \text { lipoprotein lipase } \\ \text { MAFbx } & \text { muscle atrophy F-box } \\ \text { MuRF1 } & \text { muscle ring finger 1 } \\ \text { PDK } & \text { pyruvate dehydrogenase kinase } \\ \text { PFK } & \text { phosphofructokinase } \\ \text { PGC1 } \alpha & \text { peroxisome proliferator-activated receptor } \\ & \gamma \text { coactivator1 } \alpha \\ \text { SCD } & \text { stearoyl CoA desaturase } \\ \text { SREBP1c } & \text { sterol regulatory element binding protein-1c } \\ \text { UCP } & \text { uncoupling protein } \\ \beta-H A D & \beta \text {-hydroxy-acyl-CoA dehydrogenase }\end{array}$

\section{Introduction}

Skeletal muscle is considered to be the most abundant organ in the human body, comprising approximately $40 \%$ of the total body mass [1]. Because it is also the most active metabolically, it serves as the major site of fatty acid oxidation and lipid metabolism [2]. In addition, skeletal muscle plays a key role in the regulation of glucose use. In fact, skeletal muscles are thought to account for approximately $75 \%$ of insulin-stimulated glucose uptake [3, 4]. In obesity, insulinstimulated glucose disposal is reduced in skeletal muscles [5-8]. Under these conditions, intramyocellular lipid content is increased, possibly resulting in the development of insulin resistance, a characteristic feature of chronic metabolic disorders such as type 2 diabetes [9-11]. This relationship underscores the importance of skeletal muscle in regulating events involved in metabolic disorders. Various molecular pathways, in which the regulatory roles of peroxisome proliferator-activated receptors (PPARs) are well recognized, have been associated with these disorders [12].

PPARs are members of the nuclear receptor superfamily and share the same structural organization as other family members [13]. They have a less-conserved ligand-independent activation domain $(\mathrm{A} / \mathrm{B})$ at the amino terminal end; a well-conserved DNA binding domain (C), consisting of two zinc finger-like structures comprising the $\alpha$-helical DNA binding motif; a hinge region (domain $\mathrm{D}$ ), implicated in interactions with cofactors; and a well-conserved ligand binding domain (LBD) at the C-terminal end (E/F domain) $[14,15]$. The ligand-dependent activation function (AF-2) 
resides within the LBD and enables heterodimerization of PPAR with its obligate retinoid $\mathrm{X}$ receptor (RXR) partner. The ligand-activated heterodimer binds to peroxisome proliferator response elements (PPREs) present in the control regions of the target genes, recruits coactivators, and stimulates transcription [16-19]. Thus, PPARs are lipophilic ligand-inducible transcription factors that form a subfamily comprising three subtypes: PPAR $\alpha$ (NR1C1) [20], which can be activated by peroxisome proliferators (hence the name) [21], PPAR $\beta / \delta$ (NR1C2), and PPAR $\gamma$ (NR1C3) [22].

Although encoded in separate genes, the three PPARs are often coexpressed at variable levels in different tissues [23, 24]. PPAR $\alpha$ is highly expressed in liver, kidney, heart, and skeletal muscles [24] and functions as a regulator for the uptake and oxidation of fatty acids, lipoprotein metabolism, and control of inflammatory responses [25, 26]. PPAR $\gamma$ is expressed predominantly in adipose tissue and regulates adipogenesis and fat storage and occurs in two isoforms, $\gamma 1$ and $\gamma 2$. The $\gamma 1$ isoform is relatively abundant in preadipocytes and is also expressed at high levels in colon epithelium and in immune cells. PPAR $\gamma 2$ is the predominant isoform in preadipocytes and adipocytes [27], and apart from its role in adipocyte differentiation, is involved in a diverse array of other biological processes including insulin sensitization and cell differentiation [28]. PPAR $\beta / \delta$ is expressed ubiquitously [24] and is also implicated in different cellular functions in the skin [29], brain [30], adipose tissue, heart, skeletal muscle [12], and inflammation [31]. This isotype is particularly implicated in tissue repair [32] and energy expenditure [33], and its activation regulates dyslipidemia, resulting in improved serum lipid profiles [34-36]. This review discusses the roles of PPAR $\beta / \delta$ in the regulation of energy metabolism in skeletal muscles and the pathways through which it exerts its action.

\section{Role in fatty acid metabolism}

In addition to skeletal muscle, white and brown adipose tissues (WATs and BATs) significantly contribute to fatty acid metabolism and energy homeostasis [37, 38]. Excess energy is stored in the form of triglycerides in WATs, and in times of energy need it is released as free fatty acids and glycerol in circulation and further used mainly by BATs, skeletal muscle, and liver. BATs produce abundant heat from fatty acid oxidation by uncoupling the production of ATP from the electron transport chain. Apart from BATs, this process of energy dissipation also takes place in skeletal muscles. Thus, skeletal muscles play an important role in coordinating metabolic processes by regulating lipid and carbohydrate catabolism along with thermogenesis. Of importance, of the three isotypes, $\mathrm{PPAR} \beta / \delta$ is the one that is predominantly expressed in skeletal muscles [39] and involved in these metabolic pathways [40].

The role of PPAR $\beta / \delta$ as a central regulator of fatty acid metabolism in skeletal muscles was established through different transgenic animal models with either muscle-specific overexpression [41, 42] or deletion of PPAR $\beta / \delta$ [43]. Germline PPAR $\beta / \delta$-null animals have been difficult to obtain because of the placental defects observed during the midgestation period [44-46]. Probably because of these difficulties, which delayed the availability of null mice, the first study to report the involvement of PPAR $\beta / \delta$ in fatty acid oxidation was performed in primary cultures of human skeletal muscle myotubes, showing that polyunsaturated fatty acids regulate $u c p-2$ expression through PPAR $\beta / \delta$ activation [39]. Experiments involving gain and loss of functions of PPAR $\beta / \delta$ further confirmed the regulatory role of this receptor in lipid metabolism in skeletal muscle cells [47]. C2C12 cells overexpressing PPAR $\beta / \delta$ and treated with a selective agonist increase the expression of genes involved in fatty acid oxidation (CPT-1), fatty acid uptake (FAT/CD36), and binding (FABP3 also called hFABP). A weak but significant dose-dependent increase in lipoprotein lipase (LPL) and acyl-CoA synthetase (ACS) mRNA levels has also been observed in these cells.

Furthermore, pharmacological activation of PPAR $\beta / \delta$ by a specific ligand (GW501516) alone or in combination with an agonist for RXR (LG101305) regulates genes involved in triglyceride hydrolysis and fatty acid oxidation, lipid use, energy uncoupling, and lipid efflux in differentiated myotubes [2]. When GW501516 or LG101305 are used separately, the response is moderate from the majority of investigated candidate target genes involved in skeletal muscle lipid and carbohydrate metabolism, such as CD36 and FABP3 (involved in fatty acid uptake and binding); SREBP1c and SCD1 and SCD2 (involved in lipogenesis); LPL, ACS4, and M-CPT1 (triglyceride hydrolysis and fatty acid oxidation); PDK4 (glucose use); ABCA1 and ApoE (lipid efflux); and adipophilin/ADRP (lipid storage). However, a high induction of the genes involved in thermogenesis and energy expenditure, such as uncoupling protein 1 (UCP1) and UCP2, results when the cells are treated with the PPAR $\beta / \delta$ ligand alone, and only UCP2 responds moderately to the RXR agonist alone. Of interest, most of these genes are synergistically upregulated on co-treatment with agonists for both receptors.

These observations suggested a potential collaboration between PPAR $\beta / \delta$ and RXR ligands in skeletal muscle cells with regard to metabolic pathways. This concept was further consolidated by another study in which a microarray analysis of GW501516-treated myotubes revealed that PPAR $\beta / \delta$ controls fatty acid oxidation by regulating genes involved in fatty acid uptake, fatty acid $\beta$-oxidation, and mitochondrial respiration [48]. In addition to the effect of GW501516 on myotubes, the role of PPAR $\beta / \delta$ in metabolic homeostasis in skeletal muscles was also confirmed in vivo. Effects similar to those mentioned above have been observed in skeletal muscles of mice treated with GW501516. More important, administration of GW501516 to mice fed a high-fat diet ameliorates diet-induced obesity and insulin resistance. These outcomes are accompanied by enhanced metabolic rate and fatty acid $\beta$-oxidation, an increased number of mitochondria, and a marked reduction in lipid droplets, indicating that the effects of the PPAR $\beta / \delta$ agonist on skeletal muscles might have a significant efficacy against diet-induced obesity. Furthermore, treatment with GW501516 prevents diabetes in 
genetically obese $o b / o b$ mice not only by affecting the change in body weight but also by significantly decreasing plasma glucose and insulin levels. Collectively, these observations thus suggest that the inducing effects of the PPAR $\beta / \delta$ agonist on fatty acid oxidation and energy expenditure result in amelioration of obesity and insulin resistance in obese animals, which might be of therapeutic significance.

In addition to in vivo activation of PPAR $\beta / \delta$ through a specific agonist, a study involving transgenic mice with muscle-specific overexpression of the receptor [41] has been performed to decipher the role of PPAR $\beta / \delta$ as a key target in metabolic disorders in skeletal muscles. Muscle-specific $\mathrm{PPAR} \beta / \delta$ overexpression results in decreased body fat content without alteration in lean mass. A large reduction in the adipose pad weight resulting from a decrease in the adipocyte cell size has also been observed [41]. Thus, PPAR $\beta / \delta$ activation leads to increased lipid catabolism in muscle, thereby decreasing its accumulation in adipose tissue and resulting in beneficial effects in preventing disorders that result from fat accumulation. Apart from the increased $\mathrm{PPAR} \beta / \delta$ activity through ligand activation or its overexpression, mice in which PPAR $\beta / \delta$ has been selectively ablated in myocytes further confirmed the pivotal role of the receptor in regulating metabolic pathways in skeletal muscles. Muscles in these mice have a lower oxidative capacity that precedes the development of obesity and diabetes [43]. Transcript levels are lower in these mutant mice for genes controlling lipolysis (LPL), fatty acid uptake (FAT/CD36), binding (hFABP/FABP3), activation (LCAS), and $\beta$-oxidation (LCAD, MCAD, SCAD, and $\beta$-HAD), the TCA cycle (CS), and UCP3, whereas two genes of the glycolytic pathway (PFK and GLUT4) remain unaltered, thus confirming once more that PPAR $\beta / \delta$ controls fatty acid metabolism in skeletal muscles. In comparison to their control littermates, the mutant mice show a significant increase in body weight when fed a high-fat diet and are insulin resistant and glucose intolerant. Even on a regular diet, these mutant mice gain more weight than do control animals. This increased body weight results from increased body fat content and increased adipocyte size in WATs but not from increased muscle weight. This phenotype is most probably a consequence of the impaired fatty acid breakdown resulting from deletion of $\operatorname{PPAR} \beta / \delta$, which results in increased fat storage in adipose tissue.

\section{PPARß/ $\delta$ activation leads to muscle fiber switching}

One of the roles of PPAR $\beta / \delta$ is to control the skeletal muscle fiber type composition [41, 42]. Depending on metabolic properties and type of myosin heavy chain, skeletal muscle fibers can be classified into type I (oxidative/slow) and type II (glycolytic/fast) fibers. The oxidative slow-twitch fibers have large amounts of mitochondria and high levels of myoglobin and mainly use oxidative metabolism to provide a stable and long-lasting supply of ATP; thus, they are fatigueresistant $[49,50]$, whereas the fast-twitch glycolytic fibers have fewer mitochondria and rely on glycolytic metabolism as a major energy source and are fatigable [51-53].

$\mathrm{PPAR} \beta / \delta$ overexpression leads to an increase in the percentage of type I fibers [41]. As a consequence, there is an increase of both enzymatic activity (CS and $\beta-H A D)$ and expression of genes implicated in oxidative metabolism (UCP2, hFABP/FABP3). Moreover, a transgenic mouse with a constitutively active form of PPAR $\beta / \delta$ has been generated [42]. This mouse expresses a transgene in which the VP16 activation domain is fused to the $\mathrm{N}$-terminus of full-length $\mathrm{PPAR} \beta / \delta$ in an expression vector under the control of the human $\alpha$-skeletal actin promoter, allowing expression specifically in skeletal muscles. Expression of this constitutively active form of PPAR $\beta / \delta$ results in a profound and coordinated increase in oxidation enzymes, mitochondrial activity (COXII, COXIV, UCP2, and UCP3), and production of characteristic type I fiber proteins, such as myoglobin and troponin I [42]. In addition, administration of the PPAR $\beta / \delta$ agonist GW501516 has similar effects, thus providing evidence that activation of endogenous PPAR $\beta / \delta$ affects fiber type composition towards an increased proportion of type I fibers. This effect of PPAR $\beta / \delta$ is mediated through its transcriptional coregulator PGC1 $\alpha$ [43] (Figure 1). Mice with a skeletal muscle-specific PPAR $\beta / \delta$ deletion have a reduced level of PGC $1 \alpha$ expression. In fact, there is a conserved PPRE in the promoter region of the PGC1 $\alpha$ gene in both mouse and human, and PPAR $\beta / \delta$ agonist treatment stimulates the $\mathrm{PGC} 1 \alpha$ promoter through this specific PPRE (Figure 1).

Previous studies have also reported PGC1 $\alpha$ to be an important regulator of the maintenance of the slow-twitch muscle fiber type $[54,55]$. Of interest, PGC1 $\alpha$ exhibits a high level of expression in the slow-twitch oxidative muscles rather than the fast-twitch glycolytic fibers [55]. Also in humans, a high level of expression of both PPAR $\beta / \delta$ and PGC1 $\alpha$ has been observed in biopsies from cyclists who generally have a high proportion of type I muscle fibers. A decrease in the expression of both is noted in patients with spinal cord injuries resulting in a loss of type I fibers [56]. Apart from $\mathrm{PPAR} \beta / \delta$ and $\mathrm{PGC} 1 \alpha$, another important regulator implicated in the maintenance of muscle fiber composition is calcineurin [57, 58]. PPAR $\beta / \delta$ activation is associated with a calcineurin-dependent effect on muscle morphology that enhances the oxidative phenotype, thus suggesting the involvement of a calcineurin-dependent signaling pathway in PPAR $\beta / \delta$-promoted muscle remodeling [59]. Moreover, the phenotype exhibited by transgenic mice expressing higher levels of calcineurin, calmodulin-dependent kinase, or PGC1 $\alpha$ [60-62] is similar to that of mice overexpressing the activated form of $\mathrm{PPAR} \beta / \delta$ in skeletal muscle [42], indicating a possible link between these signaling pathways.

\section{PPAR $/ \delta$-mediated muscle fiber transformation protects against obesity}

There is a correlation between the composition of specific muscle fiber and the development of obesity and diabetes. 


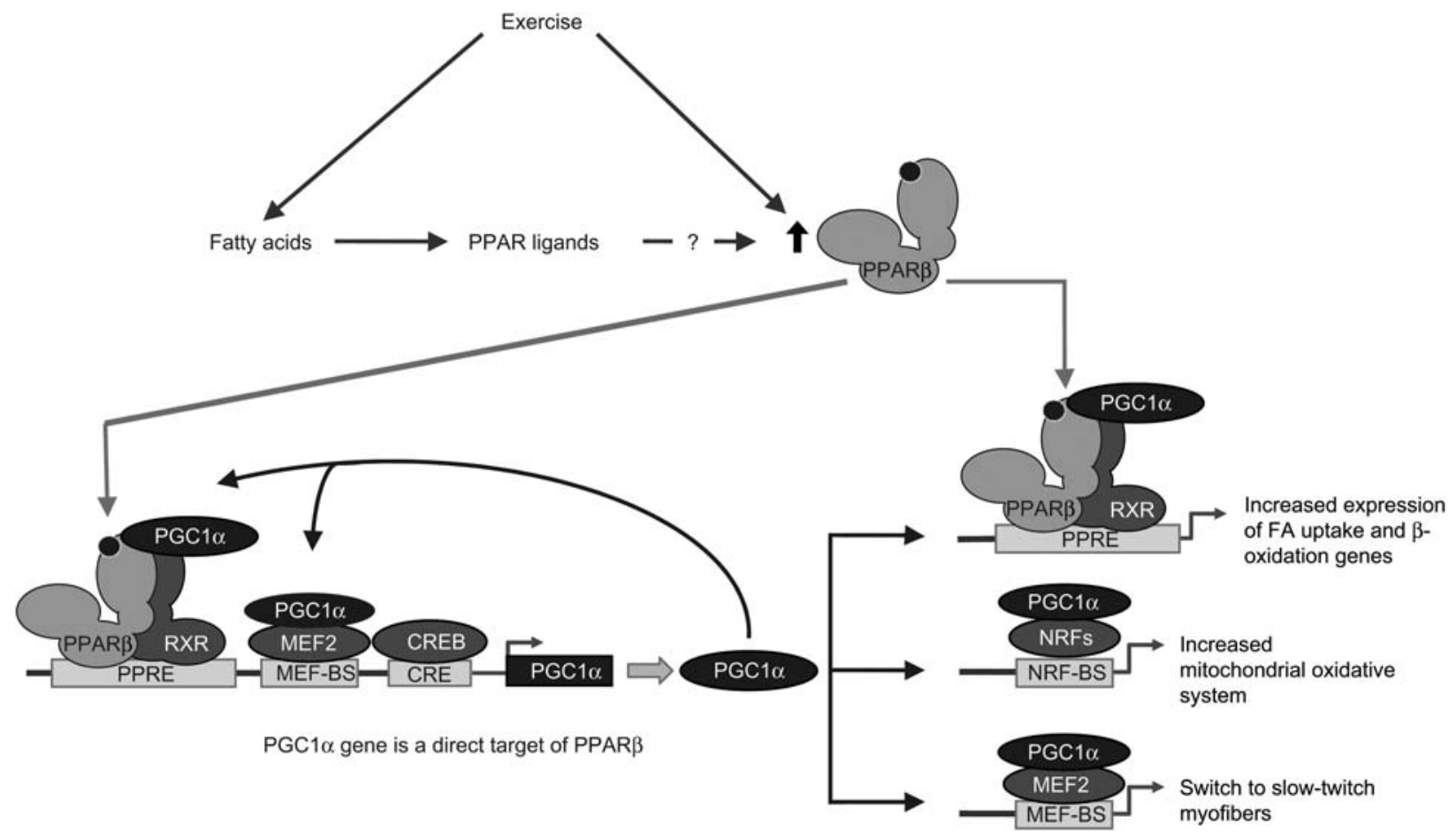

Figure 1 Model of exercise-induced metabolic pathways and fiber type switching in skeletal muscle cells.

The promoter of the PGC1 $\alpha$ gene comprises a PPRE, a myocyte-specific enhancer factor (MEF) binding site (MEF-BS), and a cAMP response element (CRE). The PGC1 $\alpha$ promoter is stimulated by muscle contraction that induces a calcium-signaling pathway, which activates CREB and MEF2 via $\mathrm{Ca}^{2+}$ /calmodulin-dependent kinase IV (CaMKIV) and calcineurin A. Exercise can increase the level of PPAR $\beta / \delta$ ligands (fatty acids) and furthermore increases PPAR $\beta / \delta$ levels through an unknown mechanism. Exercise-increased PPAR $\beta / \delta$ activity further stimulates the expression of PGC1 $\alpha$. By coactivating MEF2 and PPAR $\beta / \delta, P G C 1 \alpha$ fuels a positive feed-forward signal to further increase PGC1 $\alpha$ expression. In turn, PGC1 $\alpha$ potentiates PPAR $\beta / \delta / R X R$ heterodimers that stimulate the expression of genes involved in fatty acid uptake and $\beta$-oxidation. It also stimulates the expression of nuclear respiratory factor 1 (NRF1) and NRF2, thus leading to enhanced expression of nuclear-encoded mitochondrial genes. Finally, through coactivation of MEF2, PGC1 $\alpha$ regulates the switch to the expression of slow-twitch muscle fiber genes.

Skeletal muscles with reduced oxidative capacity, increased glycolytic capacity, and a decreased percentage of type I fibers are observed in both obese [63, 64] and diabetic patients [65]. Animals with body weight gain induced by a high-fat diet have fewer type I muscle fibers [66], as do animals with a skeletal muscle-specific deletion of PPAR $\beta / \delta$. This fiber type switching in the skeletal muscles towards a lower oxidative capacity is the causative factor in the development of obesity and diabetes [43]. Along the same line of evidence, mice overexpressing the activated form of PPAR $\beta / \delta$ in skeletal muscles or wild-type mice administered a PPAR $\beta / \delta$-specific agonist along with a high-fat diet are resistant to obesity. This finding signifies that muscle fiber conversion to type I due to activation of PPAR $\beta / \delta$ in these animals exerts a protective effect against obesity [42].

\section{Enhanced PPARß/ס-dependent muscle performance}

Skeletal muscle performance is dependent on the distribution of fiber types. Exercise training increases PPAR $\beta / \delta$ expression and, in parallel, oxidative fibers [41]. This pattern has been confirmed in individuals showing increased PPAR $\beta / \delta$ levels after exercise training [67-70]. As already mentioned, the increase in the number of fibers with oxidative capability, an effect induced by muscle-specific overexpression of PPAR $\beta / \delta$ [41], is similar to that observed in exercised mice [71-73] and humans [74], suggesting that upregulation of $\mathrm{PPAR} \beta / \delta$ plays an important role in muscle adaptation to exercise. Transgenic mice expressing constitutively active $\mathrm{PPAR} \beta / \delta$ have a significantly enhanced running capacity [42]. In contrast, PPAR $\beta / \delta$-null mice show reduced endurance [43]. Collectively, these observations favor a strong role for activated PPAR $\beta / \delta$ in the physical performance of skeletal muscles. In fact, the PPAR $\beta / \delta$ ligand GW501516 has been classified as a doping substance by the World AntiDoping Agency because of its ability to influence muscle performance [75], and two of its major urinary metabolites have been characterized for identification of the drug in routine doping controls [76]. Mechanistically, PPAR $\beta / \delta$ can enhance running endurance through activation of AMPK signaling [77, 78] as AMPK is activated during exercise training (Figure 2) [79, 80]. Of interest, a decrease in running capacity has been observed in mice with defective AMPK signaling in muscle [81, 82]. More important, mice with an 


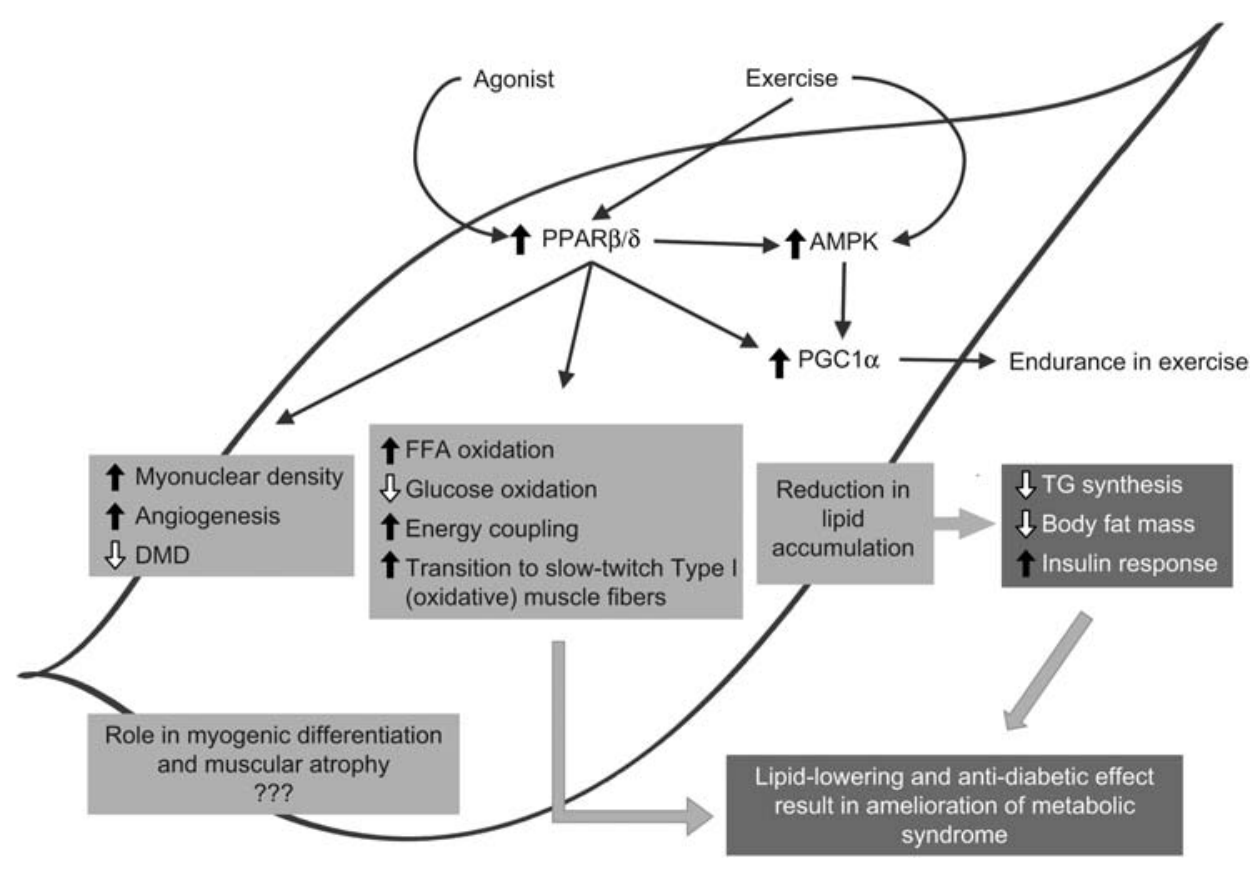

Figure 2 Actions of PPAR $\beta / \delta$ in skeletal muscles.

Pharmacological activation of PPAR $\beta / \delta$ by a specific ligand has been shown to regulate expression levels of genes involved in triglyceride hydrolysis and free fatty acid oxidation, lipid use, energy expenditure, and muscle fiber type switching in skeletal muscle, in turn resulting in decreased body fat mass and enhanced insulin response. Both the lipid lowering and the anti-diabetic effects exerted by the inducing effects of PPAR $\beta / \delta$ result in the amelioration of symptoms of metabolic disorders. In addition, exercise training induces fiber type switching accompanied by increased PPAR $\beta / \delta$ levels and AMPK, resulting in endurance in exercise through upregulation of the common effector molecule, PGC1 $\alpha$. Pharmacological activation of PPAR $\beta / \delta$ also promotes myonuclear accretion and angiogenesis in skeletal muscle and protects against Duchenne muscular dystrophy (DMD). However, the role of PPAR $\beta / \delta$ in myogenic differentiation and muscular atrophy remains to be deciphered. FFA, free fatty acids; TG, triglycerides.

activated form of PPAR $\beta / \delta$ in skeletal muscle show a constitutive high level of AMPK expression [83], and a physical association between exercise-activated AMPK and PPAR $\beta$ / $\delta$ is observed, revealing a molecular link most probably contributing to the running endurance phenotype observed after activation of PPAR $\beta / \delta$.

The mechanism through which PPAR $\beta / \delta$ is upregulated during exercise remains unclear, although one plausible explanation is that exercise results in recruitment of fatty acids that might act as endogenous ligands for PPAR $\beta / \delta$, thus resulting in its activation and stimulation of its target genes (Figure 1). Another mechanism probably involves mediation through upregulation of $\mathrm{PGC} 1 \alpha$, as exercise training leads to increased levels of PGC $1 \alpha$ in skeletal muscles $[55,84]$, which might in turn lead to increased activity of $\mathrm{PPAR} \beta / \delta$ because of its interaction with $\mathrm{PGC} 1 \alpha$. These two possible mechanisms are, of course, not mutually exclusive.

\section{Expert opinion}

$\operatorname{PPAR} \beta / \delta$ is a crucial player in regulating lipid metabolic pathways in skeletal muscle, which in turn affects other organ systems, resulting in the amelioration of metabolic disorders (Figure 2). Muscle-specific deletion of this PPAR isotype provides additional proof for its involvement in muscle physiology. In these mutated animals, a partial compensatory role of PPAR $\alpha$ cannot be excluded because PPAR $\alpha$ is also expressed in tissues with high rates of fatty acid oxidation, including muscle [85-87]. Furthermore, activation of PPAR $\alpha$ induces expression of genes involved in fatty acid oxidation. A significant decrease in the expression levels of these genes has been observed in PPAR $\alpha$-null mice, but in tissues other than skeletal muscle [88]. Thus, the oxidative capacity of skeletal muscle appears not to be compromised in PPAR $\alpha$-null mice, further strengthening the importance of $\mathrm{PPAR} \beta / \delta$ in metabolic regulation in this tissue. However, a recent report [89] suggests that PPAR $\beta / \delta$ is dispensable in skeletal muscles for regulating pathways involved in lipid metabolism. In that study, deletion of PPAR $\beta / \delta$ alone did not exert a significant effect on the $\beta$-oxidation pathway. Furthermore, there was apparently a lack of compensation between these two receptors, as double deletion of PPAR $\alpha$ and $P P A R \beta / \delta$ resulted in a phenotype more like that of PPAR $\alpha$-null mice. Thus, it is currently difficult to definitively attribute exclusive roles to each of these two receptors in muscle metabolism. The reasons behind the discrepancies remain unclear. A better understanding can be obtained with muscle-specific deletion of PPAR $\alpha$ and a combined musclespecific deletion of both $\operatorname{PPAR} \alpha$ and $\operatorname{PPAR} \beta / \delta$, which remain to be performed. In animals with a germline deletion of PPAR $\alpha$, the muscle phenotype can, in part, result from the absence of PPAR $\alpha$ in other tissues. 
Furthermore, what has gone unexplored so far is the function of PPAR $\beta / \delta$ in muscle cell differentiation and thus its role in skeletal muscle disorders, such as muscle atrophy or hypertrophy. Apart from a few recent, conflicting reports [90, 91], the role of PPAR $\beta / \delta$ in the muscle atrophic program has not been addressed. What is known is that acute administration of a PPAR $\beta / \delta$ agonist activates ubiquitin proteasome proteolytic-dependent skeletal muscle atrophy [90], and although the muscle-specific E3 ubiquitin ligases MuRF1 and MAFbx are upregulated, no 20S proteasome transcriptional activity has been detected. Obviously, further studies with muscle-specific overexpression or deletion of PPAR $\beta$ / $\delta$ are needed to clarify its possible role in the muscle atrophy program.

Pharmacological activation of $\operatorname{PPAR} \beta / \delta$ is protective against Duchenne muscular dystrophy in $m d x$ mice [91] and promotes myonuclear accretion [92]. Age-related muscle atrophy is associated with reduced numbers of oxidative myofibers, and activation of PPAR $\beta / \delta$ promotes fusion of muscle progenitor cells to form myofibers and increases myonuclear density. Ligand-induced activation of PPAR $\beta / \delta$ also promotes calcineurin-dependent fiber remodeling and angiogenesis in mouse skeletal muscle through upregulation of myogenic and angiogenic markers [59]. In spite of these interesting observations, modulation by PPAR $\beta / \delta$ of the different molecular pathways involved in myogenic differentiation remains to be elucidated, which might provide further insights into the roles of PPAR $\beta / \delta$ in muscular dystrophies.

\section{Outlook}

To counter the growing threat that the metabolic syndrome poses, one can dream of a "magic pill" with multifaceted effects that enable combating the various aspects of this disorder. The impact of PPAR $\beta / \delta$ activation on hypertriglyceridemia and insulin resistance through enhancement of fatty acid catabolism and energy expenditure in both adipose tissue and skeletal muscle confers on this nuclear receptor strong potential in the fight against obesity and diabetes. Its promising effects in different tissues make it the most favorable target for future therapeutic interventions. The potent ligand for PPAR $\beta / \delta$, GW501516, which has been used in most of the preclinical studies described here, is already in clinical trials for the treatment of dyslipidemia and metabolic syndrome. Observations from Phase I clinical studies have confirmed its efficacy in altering the serum lipid profile, including increasing triglyceride clearance after a fatty meal in treated groups, thus strengthening its potential for functionality in people in addition to what has been previously observed in different animal models for dyslipidemia [93]. Furthermore, in Phase II studies, the PPAR $\beta / \delta$ agonist GW501516 improved multiple metabolic disorders associated with the metabolic syndrome, most probably through an increase in skeletal muscle fatty acid oxidation [94]. In that study, the PPAR $\beta / \delta$ agonist was more efficient than the PPAR $\alpha$ agonist GW590735. The promise that GW501516 has shown in these clinical trials will hopefully not be undone by adverse effects that might emerge when large cohorts are treated. PPAR $\beta / \delta$ is involved in various tissue repair processes, such as cell survival, differentiation, proliferation, and migration. Such processes will have to be monitored carefully during long-term treatment with candidate drugs targeting PPAR $\beta / \delta$.

\section{Highlights}

- Skeletal muscle is a major site of fatty acid catabolism and energy expenditure.

- PPAR $\beta / \delta$ is the isotype predominantly expressed in skeletal muscles and plays a pivotal role in muscular fatty acid $\beta$-oxidation.

- The role of PPAR $\beta / \delta$ as a central regulator of fatty acid metabolism in skeletal muscles has been established through in vitro and in vivo approaches involving transgenic animal models with either muscle-specific overexpression or deletion of PPAR $\beta / \delta$.

- Pharmacological activation of PPAR $\beta / \delta$ by a selective ligand regulates genes involved in lipid use, triglyceride hydrolysis, fatty acid oxidation, energy expenditure, and lipid efflux in skeletal muscle.

- Agonist-induced effects of PPAR $\beta / \delta$ result in amelioration of obesity, insulin resistance, and glucose intolerance, revealing its potential as a therapeutic target in metabolic disorders.

- PPAR $\beta / \delta$ activation alters the composition of the muscle fibers towards the slow oxidative type I, in support of its protective effect against metabolic syndrome and enhancement of muscle performance during endurance exercise.

- PPAR $\beta / \delta$-mediated regulation of myogenic differentiation and muscle atrophic signaling pathways remains unexplored.

- Clinical studies related to the safety and efficacy of $\mathrm{PPAR} \beta / \delta$ agonists are ongoing.

\section{Acknowledgments}

The work performed in the authors' laboratory was supported by the Swiss National Science Foundation, the National Center of Competence in Research "Frontiers in Genetics", the BonizziTheler Stiftung, the Etat de Vaud and the European Union funded large collaborative project TORNADO. We thank Nathalie Constantin for her help in preparing the figures.

\section{References}

1. Janssen I, Heymsfield SB, Baumgartner RN, Ross R. Estimation of skeletal muscle mass by bioelectrical impedance analysis. J Appl Physiol 2000;89:465-71.

2. Dressel U, Allen TL, Pippal JB, Rohde PR, Lau P, Muscat GE. The peroxisome proliferator-activated receptor beta/delta agonist, GW501516, regulates the expression of genes involved in lipid 
catabolism and energy uncoupling in skeletal muscle cells. Mol Endocrinol 2003;17:2477-93.

3. DeFronzo RA, Jacot E, Jequier E, Maeder E, Wahren J, Felber JP. The effect of insulin on the disposal of intravenous glucose. Results from indirect calorimetry and hepatic and femoral venous catheterization. Diabetes 1981;30:1000-7.

4. Shulman GI, Rothman DL, Jue T, Stein P, DeFronzo RA, Shulman RG. Quantitation of muscle glycogen synthesis in normal subjects and subjects with non-insulin-dependent diabetes by 13C nuclear magnetic resonance spectroscopy. N Engl J Med 1990;322:223-8.

5. Furler SM, Poynten AM, Kriketos AD, Lowy AJ, Ellis BA, Maclean EL, Courtenay BG, Kraegen EW, Campbell LV, Chisholm DJ. Independent influences of central fat and skeletal muscle lipids on insulin sensitivity. Obes Res 2001;9:535-43.

6. Kraegen EW, Clark PW, Jenkins AB, Daley EA, Chisholm DJ, Storlien LH. Development of muscle insulin resistance after liver insulin resistance in high-fat-fed rats. Diabetes 1991; 40:1397-403.

7. Phillips DI, Caddy S, Ilic V, Fielding BA, Frayn KN, Borthwick AC, Taylor R. Intramuscular triglyceride and muscle insulin sensitivity: evidence for a relationship in nondiabetic subjects. Metabolism 1996;45:947-50.

8. Pan DA, Lillioja S, Kriketos AD, Milner MR, Baur LA, Bogardus C, Jenkins AB, Storlien LH. Skeletal muscle triglyceride levels are inversely related to insulin action. Diabetes 1997;46: 983-8.

9. Savage DB, Petersen KF, Shulman GI. Disordered lipid metabolism and the pathogenesis of insulin resistance. Physiol Rev 2007;87:507-20.

10. Goodpaster BH, Kelley DE. Role of muscle in triglyceride metabolism. Curr Opin Lipidol 1998;9:231-6.

11. Hulver MW, Berggren JR, Cortright RN, Dudek RW, Thompson RP, Pories WJ, MacDonald KG, Cline GW, Shulman GI, Dohm GL, Houmard JA. Skeletal muscle lipid metabolism with obesity. Am J Physiol Endocrinol Metab 2003;284:E741-7.

12. Desvergne B, Michalik L, Wahli W. Transcriptional regulation of metabolism. Physiol Rev 2006;86:465-514.

13. Chawla A, Repa JJ, Evans RM, Mangelsdorf DJ. Nuclear receptors and lipid physiology: opening the X-files. Science 2001;294:1866-70.

14. Miyamoto T, Kakizawa T, Ichikawa K, Nishio S, Takeda T, Suzuki S, Kaneko A, Kumagai M, Mori J, Yamashita K, Sakuma T, Hashizume K. The role of hinge domain in heterodimerization and specific DNA recognition by nuclear receptors. Mol Cell Endocrinol 2001;181:229-38.

15. Tomaru T, Satoh T, Yoshino S, Ishizuka T, Hashimoto K, Monden T, Yamada M, Mori M. Isolation and characterization of a transcriptional cofactor and its novel isoform that bind the deoxyribonucleic acid-binding domain of peroxisome proliferator-activated receptor-gamma. Endocrinology 2006;147:37788.

16. Nolte RT, Wisely GB, Westin S, Cobb JE, Lambert MH, Kurokawa R, Rosenfeld MG, Willson TM, Glass CK, Milburn MV. Ligand binding and co-activator assembly of the peroxisome proliferator-activated receptor-gamma. Nature 1998;395:13743.

17. Schulman IG, Shao G, Heyman RA. Transactivation by retinoid $\mathrm{X}$ receptor-peroxisome proliferator-activated receptor gamma (PPARgamma) heterodimers: intermolecular synergy requires only the PPARgamma hormone-dependent activation function. Mol Cell Biol 1998;18:3483-94.

18. Gearing KL, Gottlicher M, Teboul M, Widmark E, Gustafsson JA. Interaction of the peroxisome-proliferator-activated receptor and retinoid X receptor. Proc Natl Acad Sci USA 1993;90: $1440-4$.

19. Ijpenberg A, Jeannin E, Wahli W, Desvergne B. Polarity and specific sequence requirements of peroxisome proliferator-activated receptor (PPAR)/retinoid X receptor heterodimer binding to DNA. A functional analysis of the malic enzyme gene PPAR response element. J Biol Chem 1997;272:20108-17.

20. Nuclear Receptors Nomenclature Committee. A unified nomenclature system for the nuclear receptor superfamily. Cell 1999; 97:161-3.

21. Issemann I, Green S. Activation of a member of the steroid hormone receptor superfamily by peroxisome proliferators. Nature 1990;347:645-50.

22. Dreyer C, Krey G, Keller H, Givel F, Helftenbein G, Wahli W. Control of the peroxisomal beta-oxidation pathway by a novel family of nuclear hormone receptors. Cell 1992;68:879-87.

23. Braissant O, Wahli W. Differential expression of peroxisome proliferator-activated receptor-alpha, -beta, and -gamma during rat embryonic development. Endocrinology 1998;139:2748-54.

24. Braissant O, Foufelle F, Scotto C, Dauca M, Wahli W. Differential expression of peroxisome proliferator-activated receptors (PPARs): tissue distribution of PPAR-alpha, -beta, and -gamma in the adult rat. Endocrinology 1996;137:354-66.

25. Desvergne B, Wahli W. Peroxisome proliferator-activated receptors: nuclear control of metabolism. Endocr Rev 1999;20:64988.

26. Devchand PR, Keller H, Peters JM, Vazquez M, Gonzalez FJ, Wahli W. The PPARalpha-leukotriene B4 pathway to inflammation control. Nature 1996;384:39-43.

27. Mukherjee R, Jow L, Croston GE, Paterniti JR Jr. Identification, characterization, and tissue distribution of human peroxisome proliferator-activated receptor (PPAR) isoforms PPARgamma2 versus PPARgamma1 and activation with retinoid $\mathrm{X}$ receptor agonists and antagonists. J Biol Chem 1997;272:8071-6.

28. Berger JP, Akiyama TE, Meinke PT. PPARs: therapeutic targets for metabolic disease. Trends Pharmacol Sci 2005;26:244-51.

29. Michalik L, Wahli W. Peroxisome proliferator-activated receptors (PPARs) in skin health, repair and disease. Biochim Biophys Acta 2007;1771:991-8.

30. Hall MG, Quignodon L, Desvergne B. Peroxisome proliferatoractivated receptor beta/delta in the brain: facts and hypothesis. PPAR Res 2008;2008:780452-62.

31. Kostadinova R, Wahli W, Michalik L. PPARs in diseases: control mechanisms of inflammation. Curr Med Chem 2005;12: 2995-3009.

32. Michalik L, Wahli W. Involvement of PPAR nuclear receptors in tissue injury and wound repair. J Clin Invest 2006;116:598606.

33. Vosper H, Patel L, Graham TL, Khoudoli GA, Hill A, Macphee CH, Pinto I, Smith SA, Suckling KE, Wolf CR, Palmer CN. The peroxisome proliferator-activated receptor delta promotes lipid accumulation in human macrophages. J Biol Chem 2001; 276:44258-65.

34. Grimaldi PA. Regulatory functions of PPARbeta in metabolism: implications for the treatment of metabolic syndrome. Biochim Biophys Acta 2007;1771:983-90.

35. Leibowitz MD, Fievet C, Hennuyer N, Peinado-Onsurbe J, Duez H, Bergera J, Cullinan CA, Sparrow CP, Baffic J, Berger GD, Santini C, Marquis RW, Tolman RL, Smith RG, Moller DE, Auwerx J. Activation of PPARdelta alters lipid metabolism in $\mathrm{db} / \mathrm{db}$ mice. FEBS Lett 2000;473:333-6.

36. Oliver WR Jr, Shenk JL, Snaith MR, Russell CS, Plunket KD, Bodkin NL, Lewis MC, Winegar DA, Sznaidman ML, Lambert MH, Xu HE, Sternbach DD, Kliewer SA, Hansen BC, Willson 
TM. A selective peroxisome proliferator-activated receptor delta agonist promotes reverse cholesterol transport. Proc Natl Acad Sci USA 2001;98:5306-11.

37. Lowell BB, Spiegelman BM. Towards a molecular understanding of adaptive thermogenesis. Nature 2000;404:652-60.

38. Spiegelman BM, Flier JS. Obesity and the regulation of energy balance. Cell 2001;104:531-43.

39. Chevillotte E, Rieusset J, Roques M, Desage M, Vidal H. The regulation of uncoupling protein-2 gene expression by omega6 polyunsaturated fatty acids in human skeletal muscle cells involves multiple pathways, including the nuclear receptor peroxisome proliferator-activated receptor beta. J Biol Chem 2001; 276:10853-60.

40. Wang YX, Lee CH, Tiep S, Yu RT, Ham J, Kang H, Evans RM. Peroxisome-proliferator-activated receptor delta activates fat metabolism to prevent obesity. Cell 2003;113:159-70.

41. Luquet S, Lopez-Soriano J, Holst D, Fredenrich A, Melki J, Rassoulzadegan M, Grimaldi PA. Peroxisome proliferator-activated receptor delta controls muscle development and oxidative capability. FASEB J 2003;17:2299-301.

42. Wang YX, Zhang CL, Yu RT, Cho HK, Nelson MC, BayugaOcampo CR, Ham J, Kang H, Evans RM. Regulation of muscle fiber type and running endurance by PPARdelta. PLoS Biol 2004;2:1532-9.

43. Schuler M, Ali F, Chambon C, Duteil D, Bornert JM, Tardivel A, Desvergne B, Wahli W, Chambon P, Metzger D. PGC1alpha expression is controlled in skeletal muscles by PPARbeta, whose ablation results in fiber-type switching, obesity, and type 2 diabetes. Cell Metab 2006;4:407-14.

44. Peters JM, Lee SS, Li W, Ward JM, Gavrilova O, Everett C, Reitman ML, Hudson LD, Gonzalez FJ. Growth, adipose, brain, and skin alterations resulting from targeted disruption of the mouse peroxisome proliferator-activated receptor beta(delta). Mol Cell Biol 2000;20:5119-28.

45. Barak Y, Liao D, He W, Ong ES, Nelson MC, Olefsky JM, Boland R, Evans RM. Effects of peroxisome proliferator-activated receptor delta on placentation, adiposity, and colorectal cancer. Proc Natl Acad Sci USA 2002;99:303-8.

46. Nadra K, Anghel SI, Joye E, Tan NS, Basu-Modak S, Trono D, Wahli W, Desvergne B. Differentiation of trophoblast giant cells and their metabolic functions are dependent on peroxisome proliferator-activated receptor beta/delta. Mol Cell Biol 2006;26:3266-81.

47. Holst D, Luquet S, Nogueira V, Kristiansen K, Leverve X, Grimaldi PA. Nutritional regulation and role of peroxisome proliferator-activated receptor delta in fatty acid catabolism in skeletal muscle. Biochim Biophys Acta 2003;1633:43-50.

48. Tanaka T, Yamamoto J, Iwasaki S, Asaba H, Hamura H, Ikeda Y, Watanabe M, Magoori K, Ioka RX, Tachibana K, Watanabe Y, Uchiyama Y, Sumi K, Iguchi H, Ito S, Doi T, Hamakubo T, Naito M, Auwerx J, Yanagisawa M, Kodama T, Sakai J. Activation of peroxisome proliferator-activated receptor delta induces fatty acid beta-oxidation in skeletal muscle and attenuates metabolic syndrome. Proc Natl Acad Sci USA 2003;100: 15924-9.

49. Schiaffino S, Serrano A. Calcineurin signaling and neural control of skeletal muscle fiber type and size. Trends Pharmacol Sci 2002;23:569-75.

50. Spangenburg EE, Booth FW. Molecular regulation of individual skeletal muscle fibre types. Acta Physiol Scand 2003;178:41324.

51. Booth FW, Thomason DB. Molecular and cellular adaptation of muscle in response to exercise: perspectives of various models. Physiol Rev 1991;71:541-85.
52. Berchtold MW, Brinkmeier H, Muntener M. Calcium ion in skeletal muscle: its crucial role for muscle function, plasticity, and disease. Physiol Rev 2000;80:1215-65.

53. Olson EN, Williams RS. Remodeling muscles with calcineurin. Bioessays 2000;22:510-9.

54. Leone TC, Lehman JJ, Finck BN, Schaeffer PJ, Wende AR, Boudina S, Courtois M, Wozniak DF, Sambandam N, BernalMizrachi C, Chen Z, Holloszy JO, Medeiros DM, Schmidt RE, Saffitz JE, Abel ED, Semenkovich CF, Kelly DP. PGC-1alpha deficiency causes multi-system energy metabolic derangements: muscle dysfunction, abnormal weight control and hepatic steatosis. PLoS Biol 2005;3:672-87.

55. Lin J, Handschin C, Spiegelman BM. Metabolic control through the PGC-1 family of transcription coactivators. Cell Metab 2005;1:361-70.

56. Kramer DK, Ahlsen M, Norrbom J, Jansson E, Hjeltnes N, Gustafsson T, Krook A. Human skeletal muscle fibre type variations correlate with PPAR alpha, PPAR delta and PGC-1 alpha mRNA. Acta Physiol (Oxf) 2006;188:207-16.

57. Chin ER, Olson EN, Richardson JA, Yang Q, Humphries C, Shelton JM, Wu H, Zhu W, Bassel-Duby R, Williams RS. A calcineurin-dependent transcriptional pathway controls skeletal muscle fiber type. Genes Dev 1998;12:2499-509.

58. McCullagh KJ, Calabria E, Pallafacchina G, Ciciliot S, Serrano AL, Argentini C, Kalhovde JM, Lomo T, Schiaffino S. NFAT is a nerve activity sensor in skeletal muscle and controls activity-dependent myosin switching. Proc Natl Acad Sci USA 2004;101:10590-5.

59. Gaudel C, Schwartz C, Giordano C, Abumrad NA, Grimaldi PA. Pharmacological activation of PPARbeta promotes rapid and calcineurin-dependent fiber remodeling and angiogenesis in mouse skeletal muscle. Am J Physiol Endocrinol Metab 2008;295:E297-304.

60. Naya FJ, Mercer B, Shelton J, Richardson JA, Williams RS, Olson EN. Stimulation of slow skeletal muscle fiber gene expression by calcineurin in vivo. J Biol Chem 2000;275: 4545-8.

61. Lin J, Wu H, Tarr PT, Zhang CY, Wu Z, Boss O, Michael LF, Puigserver P, Isotani E, Olson EN, Lowell BB, Bassel-Duby R, Spiegelman BM. Transcriptional co-activator PGC-1 alpha drives the formation of slow-twitch muscle fibres. Nature 2002;418: 797-801.

62. Wu H, Kanatous SB, Thurmond FA, Gallardo T, Isotani E, Bassel-Duby R, Williams RS. Regulation of mitochondrial biogenesis in skeletal muscle by CaMK. Science 2002;296:349-52.

63. Hickey MS, Carey JO, Azevedo JL, Houmard JA, Pories WJ, Israel RG, Dohm GL. Skeletal muscle fiber composition is related to adiposity and in vitro glucose transport rate in humans. Am J Physiol 1995;268:E453-7.

64. Tanner CJ, Barakat HA, Dohm GL, Pories WJ, MacDonald KG, Cunningham PR, Swanson MS, Houmard JA. Muscle fiber type is associated with obesity and weight loss. Am J Physiol Endocrinol Metab 2002;282:E1191-6.

65. Lillioja S, Young AA, Culter CL, Ivy JL, Abbott WG, Zawadzki JK, Yki-Jarvinen H, Christin L, Secomb TW, Bogardus C. Skeletal muscle capillary density and fiber type are possible determinants of in vivo insulin resistance in man. J Clin Invest 1987;80:415-24.

66. Abou Mrad J, Yakubu F, Lin D, Peters JC, Atkinson JB, Hill JO. Skeletal muscle composition in dietary obesity-susceptible and dietary obesity-resistant rats. Am J Physiol 1992;262: R684-8.

67. Russell AP, Feilchenfeldt J, Schreiber S, Praz M, Crettenand A, Gobelet C, Meier CA, Bell DR, Kralli A, Giacobino JP, Deriaz 
O. Endurance training in humans leads to fiber type-specific increases in levels of peroxisome proliferator-activated receptorgamma coactivator-1 and peroxisome proliferator-activated receptor-alpha in skeletal muscle. Diabetes 2003;52:2874-81.

68. Watt MJ, Southgate RJ, Holmes AG, Febbraio MA. Suppression of plasma free fatty acids upregulates peroxisome proliferator-activated receptor (PPAR) alpha and delta and PPAR coactivator 1alpha in human skeletal muscle, but not lipid regulatory genes. J Mol Endocrinol 2004;33:533-44.

69. Mahoney DJ, Parise G, Melov S, Safdar A, Tarnopolsky MA. Analysis of global mRNA expression in human skeletal muscle during recovery from endurance exercise. FASEB J 2005;19: 1498-500.

70. Fritz T, Kramer DK, Karlsson HK, Galuska D, Engfeldt P, Zierath JR, Krook A. Low-intensity exercise increases skeletal muscle protein expression of PPARdelta and UCP3 in type 2 diabetic patients. Diabetes Metab Res Rev 2006;22:492-8.

71. Ishihara A, Inoue N, Katsuta S. The relationship of voluntary running to fibre type composition, fibre area and capillary supply in rat soleus and plantaris muscles. Eur J Appl Physiol Occup Physiol 1991;62:211-5.

72. Allen DL, Harrison BC, Maass A, Bell ML, Byrnes WC, Leinwand LA. Cardiac and skeletal muscle adaptations to voluntary wheel running in the mouse. J Appl Physiol 2001;90:1900-8.

73. Kelley G. Mechanical overload and skeletal muscle fiber hyperplasia: a meta-analysis. J Appl Physiol 1996;81:1584-8.

74. McCall GE, Byrnes WC, Dickinson A, Pattany PM, Fleck SJ. Muscle fiber hypertrophy, hyperplasia, and capillary density in college men after resistance training. J Appl Physiol 1996;81: 2004-12.

75. World Anti-Doping Agency. The 2010 prohibited list world antidoping code [homepage on the internet]. Montreal: World Anti-Doping Agency [updated November 2010]. Available at: http://www.wada-ama.org/.

76. Thevis M, Moller I, Thomas A, Beuck S, Rodchenkov G, Bornatsch W, Geyer H, Schanzer W. Characterization of two major urinary metabolites of the PPARdelta-agonist GW1516 and implementation of the drug in routine doping controls. Anal Bioanal Chem 2010;396:2479-91.

77. Kramer DK, Al-Khalili L, Perrini S, Skogsberg J, Wretenberg P, Kannisto K, Wallberg-Henriksson H, Ehrenborg E, Zierath JR, Krook A. Direct activation of glucose transport in primary human myotubes after activation of peroxisome proliferatoractivated receptor delta. Diabetes 2005;54:1157-63.

78. Kramer DK, Al-Khalili L, Guigas B, Leng Y, Garcia-Roves PM, Krook A. Role of AMP kinase and PPARdelta in the regulation of lipid and glucose metabolism in human skeletal muscle. J Biol Chem 2007;282:19313-20.

79. Chen ZP, Stephens TJ, Murthy S, Canny BJ, Hargreaves M, Witters LA, Kemp BE, McConell GK. Effect of exercise intensity on skeletal muscle AMPK signaling in humans. Diabetes 2003;52:2205-12.

80. Reznick RM, Shulman GI. The role of AMP-activated protein kinase in mitochondrial biogenesis. J Physiol 2006;574:33-9.

81. Mu J, Brozinick JT Jr, Valladares O, Bucan M, Birnbaum MJ. A role for AMP-activated protein kinase in contraction- and hypoxia-regulated glucose transport in skeletal muscle. Mol Cell 2001;7:1085-94.

82. Thomson DM, Porter BB, Tall JH, Kim HJ, Barrow JR, Winder WW. Skeletal muscle and heart LKB1 deficiency causes decreased voluntary running and reduced muscle mitochondrial marker enzyme expression in mice. Am J Physiol Endocrinol Metab 2007;292:E196-202.

83. Narkar VA, Downes M, Yu RT, Embler E, Wang YX, Banayo E, Mihaylova MM, Nelson MC, Zou Y, Juguilon H, Kang H, Shaw RJ, Evans RM. AMPK and PPARdelta agonists are exercise mimetics. Cell 2008;134:405-15.

84. Goto M, Terada S, Kato M, Katoh M, Yokozeki T, Tabata I, Shimokawa T. cDNA cloning and mRNA analysis of PGC-1 in epitrochlearis muscle in swimming-exercised rats. Biochem Biophys Res Commun 2000;274:350-4.

85. Gilde AJ, van der Lee KA, Willemsen PH, Chinetti G, van der Leij FR, van der Vusse GJ, Staels B, van Bilsen M. Peroxisome proliferator-activated receptor (PPAR) alpha and PPARbeta/ delta, but not PPARgamma, modulate the expression of genes involved in cardiac lipid metabolism. Circ Res 2003;92: 518-24.

86. Huss JM, Kelly DP. Nuclear receptor signaling and cardiac energetics. Circ Res 2004;95:568-78.

87. Kelly DP. PPARs of the heart: three is a crowd. Circ Res 2003; 92:482-4.

88. Muoio DM, MacLean PS, Lang DB, Li S, Houmard JA, Way JM, Winegar DA, Corton JC, Dohm GL, Kraus WE. Fatty acid homeostasis and induction of lipid regulatory genes in skeletal muscles of peroxisome proliferator-activated receptor (PPAR) alpha knock-out mice: evidence for compensatory regulation by PPAR delta. J Biol Chem 2002;277:26089-97.

89. Bedu E, Desplanches D, Pequignot J, Bordier B, Desvergne B. Double gene deletion reveals the lack of cooperation between PPARalpha and PPARbeta in skeletal muscle. Biochem Biophys Res Commun 2007;357:877-81.

90. Constantin D, Constantin-Teodosiu D, Layfield R, Tsintzas K, Bennett AJ, Greenhaff PL. PPARdelta agonism induces a change in fuel metabolism and activation of an atrophy programme, but does not impair mitochondrial function in rat skeletal muscle. J Physiol 2007;583:381-90.

91. Miura P, Chakkalakal JV, Boudreault L, Belanger G, Hebert RL, Renaud JM, Jasmin BJ. Pharmacological activation of PPARbeta/delta stimulates utrophin A expression in skeletal muscle fibers and restores sarcolemmal integrity in mature mdx mice. Hum Mol Genet 2009;18:4640-9.

92. Giordano C, Rousseau AS, Wagner N, Gaudel C, Murdaca J, Jehl-Pietri C, Sibille B, Grimaldi PA, Lopez P. Peroxisome proliferator-activated receptor beta activation promotes myonuclear accretion in skeletal muscle of adult and aged mice. Pflugers Arch 2009;458:901-13.

93. Sprecher DL, Massien C, Pearce G, Billin AN, Perlstein I, Willson TM, Hassall DG, Ancellin N, Patterson SD, Lobe DC, Johnson TG. Triglyceride: high-density lipoprotein cholesterol effects in healthy subjects administered a peroxisome proliferator activated receptor delta agonist. Arterioscler Thromb Vasc Biol 2007;27:359-65.

94. Riserus U, Sprecher D, Johnson T, Olson E, Hirschberg S, Liu A, Fang Z, Hegde P, Richards D, Sarov-Blat L, Strum JC, Basu S, Cheeseman J, Fielding BA, Humphreys SM, Danoff T, Moore NR, Murgatroyd P, O'Rahilly S, Sutton P, Willson T, Hassall D, Frayn KN, Karpe F. Activation of peroxisome proliferator-activated receptor (PPAR) delta promotes reversal of multiple metabolic abnormalities, reduces oxidative stress, and increases fatty acid oxidation in moderately obese men. Diabetes 2008;57:332-9. 